Acta Botanica Brasilica - 35(3): 486-490. July-September 2021. doi: 10.1590/0102-33062020abb0373

\title{
Crop yield mediated by honeybees in a star fruit orchard exhibiting atypical distyly
}

\author{
Reinaldo Rodrigo Novo, 2 (D), Natan Messias de Almeida ${ }^{2,3}$ (D), Tulio Freitas Filgueira de Sá ${ }^{4}$ (D), \\ Luiz Gonzaga Biones Ferraz ${ }^{5}$ (D), Elcida de Lima Araujo ${ }^{2,4}$ (1) and Cibele Cardoso Castro ${ }^{2,6 *}$ (1)
}

Received: August 7, 2020

Accepted: January 16, 2021

\begin{abstract}
The dependence of commercial crops on pollinators is closely related to their reproductive strategies and has direct impacts on production yields. Fruit production of Averrhoa carambola, the star fruit, is highly dependent on bee pollination. This distylous species may exhibit monomorphism associated with self-compatibility, a condition that may influence its degree of dependence on pollinators for fruit set. We evaluated the floral morphology and mating system of $A$. carambola and their relationships with pollinator dependence in an apparently pin-monomorphic orchard to address the following questions: Is the orchard indeed pin-monomorphic? Is the orchard self-compatible? Are pollination services sufficient to reach maximum productivity? Is fruit set related to the number of visits? We investigated floral morphometrics, mating system, and pollination following standard methods of plant reproduction research. The orchard exhibited pin-monomorphism and self-compatibility. Herkogamy strongly impaired spontaneous self-pollination, emphasizing the relevance of pollinators to crop yield. Considering that Apis mellifera was the only pollinator observed, and that the orchard showed pollen limitation, we recommend the implementation of pollinator management strategies. Additional studies will be needed to assess if the atypical distyly observed here occurs in other situations.
\end{abstract}

Keywords: crop pollination, distyly, ecosystem services, fruit yields, self-compatibility, pollen limitation

The dependence of plant species on pollination services largely depends on their mating and pollination systems (Klein et al. 2007), so that crops with restrictive mating systems, and/or highly specialized pollination mechanisms, tend to be more dependent on pollinators than those whose reproduction is more easily achieved (Garibaldi et al. 2011). It is therefore reasonable to expect that production among crops highly dependent on insect

1 Centro de Ciência do Sistema Terrestre, Instituto Nacional de Pesquisas Espaciais, 12227-010, São José dos Campos, SP, Brazil

2 Programa de Pós-Graduação em Biodiversidade, Departamento de Biologia, Universidade Federal Rural de Pernambuco, 52171-900, Recife, PE, Brazil 3 Universidade Estadual de Alagoas, 57604-595, Palmeira dos Índios, AL, Brazil

4 Universidade Federal de Pernambuco, 50670-901, Recife, PE, Brazil

5 Instituto Agronômico de Pernambuco, 50711-000, Recife, PE, Brazil

6 Universidade Federal do Agreste de Pernambuco, 55292-272, Garanhuns, PE, Brazil

* Corresponding author: cibele.castro@ufape.edu.br 


\section{Crop yield mediated by honeybees in a star fruit orchard exhibiting atypical distyly}

pollinators will be more impacted by their global declines (Potts et al. 2010; Lautenbach et al. 2012). Crop pollination, currently considered a threatened ecosystem service, is globally valued at approximately US \$235-577 billion annually (Giannini et al. 2015a; Potts et al. 2016), and is an important component of global food security (Smith et al. 2015). Studies focusing on pollination dependence and management of more vulnerable crops could therefore contribute to the mitigation of socioeconomic impacts caused by pollinator crisis (IPBES 2016; Potts et al. 2016).

Although more than $75 \%$ of all crops depend on pollinators for maximum yields (Klein et al. 2007), pollination dependence data is missing for many species, such as the star fruit (Averrhoa carambola L., Oxalidaceae), which originated in Tropical Asia (Núñez-Elisea \& Crane 2000 ), is widely cultivated in Brazil, where it yields ca. US\$ 97,000 (Bastos 2004). Star fruit plants exhibit distyly (Crane 1994), a floral dimorphism in which individuals produce flowers with short styles and long stamens (thrum morphs), or the inverse (pin morphs). Stigma in one morph is placed at similar position of anthers in the opposite morph, what is known as reciprocal herkogamy (Barrett \& Shore 2008). Populations of typically distylous species, however, may exhibit deviations such as monomorphism (the presence of only one floral morph), which is associated with selfcompatibility (Sakai \& Wright 2007, but see Knight Jr 1965). A. carambola is commonly cited as a self- and intramorphincompatible species (Knight Jr 1965; Saúco et al. 1993; Wong et al. 1994), although intramorph-compatibilty has been observed in some varieties (Crane 1994; Fushimi 1998).

As distylous plants can set fruits only after intermorph (interplant) crosses, pollinators are determinants for fruit production (Jacquemyn et al. 2018). Star fruit trees are highly dependent on bees for their pollination (Giannini et al. 2015b), mainly Apis mellifera L (Ray 2002), although the degree of their dependence on pollinators and pollination value are unknown in Brazil (Giannini et al. 2015a). Pollination in Brazilian orchards is mainly performed by allien A. mellifera, as well as some native bee species (SilvaJunior 2016; Wolowski et al. 2019), but the effectiveness of those pollinators has not yet been determined. Pollinator efficiency can be estimated by relating the numbers of visits to fruit set (Klein et al. 2003, Goodwin 2011; Rollin \& Garibaldi 2019).

The present study evaluated the floral morphology, mating system, and dependence on pollinators, of an apparently pin-monomorphic orchard of star fruit trees in northeastern Brazil, addressing the following questions: 1) Is the orchard pin-monomorphic? 2) Is the orchard selfcompatible? 3) Are pollination services enough to reach maximum productivity? 4) How efficient are the pollinators?

Field data were collected at the experimental station of the Pernambuco Agronomy Institute (IPA) in Ibimirim ( $8^{\circ} 32^{\prime} 15^{\prime \prime}$ S, 3741'30" W), Pernambuco State, in the semiarid region of northeastern Brazil, between Dec/2012 and Dec/2013. The periods of anthesis, pollen availability, and stigmatic receptivity (detected using $10 \%$ hydrogen peroxide; Dafni et al. 2005) were investigated on 30 bagged flowers distributed among 10 individuals.

The stigma and anther heights of five flowers collected from 20 individuals and preserved in $70 \%$ alcohol were measured using a digital caliper. Stamen and stigma heights were checked for normality using the Shapiro-Wilk test, and differences were assessed using the Wilcoxon test $(R$ Development Core Team 2015). If there was a statistical difference between anthers and stigmas, the presence of homostyly (an atypical condition, where anthers and stigmas have similar heights; Ganders 1979) would be discarded. Corolla length, total diameter, and tube diameter were also recorded in order to evaluate the accessibility of floral rewards and floral sexual elements by insect visitors.

The orchard mating system was evaluated using controlled crosses (spontaneous self-pollination - SS, self-pollination - SP, cross-pollination - CP, and natural pollination - NP), following standard methods for heterostylous species (Castro et al. 2004; see samples sizes in Tab. 1). We used around five individuals as pollen donors for $\mathrm{CP}$. The fruits produced became totally developed between 60 and 75 days after anthesis, and were then counted. Fruit sets resulting from the controlled crosses were compared using Chi-square test, in Bioestat 5.3 software (Ayres et al. 2007). Comparisons of fruit sets among the CP, SP and SS crosses yielded information on the magnitudes of the differences between fruit formation under 'ideal' pollen deposition (CP) conditions, and after self-pollination performed by pollinators and/or gravity. Comparisons between $\mathrm{CP}$, NP and $\mathrm{SS}$ were necessary to estimate the influence of pollinators on fruit set. The pollen limitation index - PLI (sensu Freitas et al. 2010) and the degree of dependence on pollinators - DDP (sensu Lázaro et al. 2014) were calculated. For PLI, negative values until 0.2 indicate the absence of PL, and values between 0.2 and 0.8 indicate low PL; values higher than 0.8 are interpreted as indicating extreme PL.

Table 1. Fruit set (\%) resulted from controlled crosses in Averhoa carambola in an experimental orchard in NE Brazil. Number of flowers used in each experiment are in given parenthesis. Different superscript letters indicate statistically different values (Chi-square test).

\begin{tabular}{|c|c|}
\hline Treatment & Fruit set \\
\hline Manual self-pollination & $29 \%(51)^{\mathrm{a}}$ \\
\hline Spontaneous self-polllination & $4 \%(80)^{\mathrm{b}}$ \\
\hline Natural pollination & $40 \%(75)^{\mathrm{c}}$ \\
\hline Cross-pollination & $52 \%(58)^{c}$ \\
\hline
\end{tabular}

Floral visitors were surveyed during focal observations of ten randomly selected individuals that were followed for one hour three times a day (at 07:00, 11:00, and 16:00) for five days (total of 15 hours). Floral visitor morphospecies, 
numbers of flowers visited, and visitor behavior (resource collection and contact with sexual elements) were recorded. Those visitors were collected for identification by specialists. In order to evaluate the efficiency of visitors as pollinators, three inflorescences were randomly selected on ten different trees, and their pre-anthesis floral buds were isolated with mesh bags. Soon after flower opening the bags were removed, and as soon as the flowers were visited by an insect, they were re-bagged. The same procedure was performed (on different inflorescences) after two insect visits. The experiments were carried out during periods of high visitation frequency, and comparisons of fruit set after one and two visits were compared using the Fisher test, using Biostat 5.3 software (Ayres et al. 2007).

A. carambola flowers were small, pink (Fig. 1), with the stigma above the anthers ( $\mathrm{W}=104, \mathrm{p}<0.05 ; \mathrm{Tab} .2)$. They were diurnal, and lasted for approximately $12 \mathrm{~h}$ (from 05:00 to 17:30), when pollen was available and the stigma receptive. Fruit set after $\mathrm{CP}$ was higher than after SP $\left(\chi^{2}=\right.$ 5.57, $\mathrm{p}<0.05)$, or after $S S\left(\chi^{2}=45.53, \mathrm{p}<0.001\right)$, but did not differ from NP $\left(\chi^{2}=1.81, p>0.05\right)$. Fruit set after NP was higher than after SS $\left(\chi^{2}=30.35, \mathrm{p}<0.001\right.$, Tab. 1$)$. The pollen limitation index was 0.23 , and the DDP was 0.9 . The flowers were visited exclusively by Apis mellifera $\mathrm{L}$, which landed on the corolla lobes and inserted their heads into the flower to collect nectar and pollen, and thus came into contact with the anthers and stigma (Fig. 1). Visits were more frequent early in the morning, declining towards the middle of the day, and then increasing again near 16:00 (Fig. 2). Fruit set after a single visit $(20.00 \pm 14.14 \%)$ and after two visits $(20.00 \pm 0.00 \%)$ did not differ $(\mathrm{p}>0.05)$.

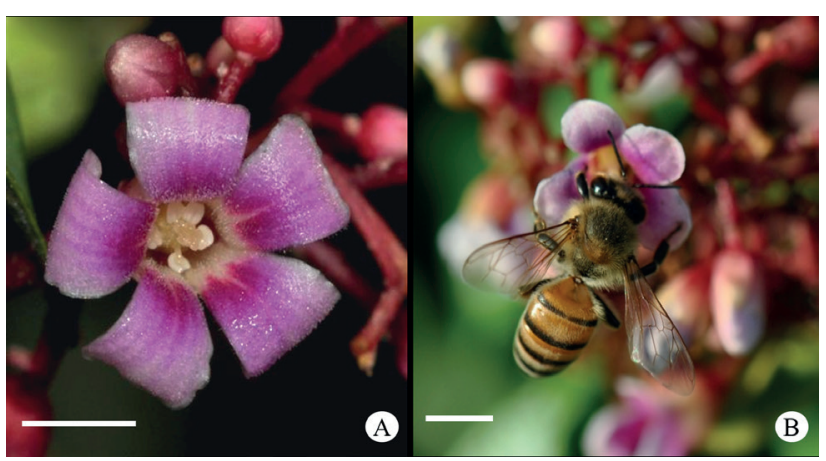

Figure 1. (A) Flower and (B) Apis mellifera pollinating star fruit flower (Averrhoa carambola, Oxalidaceae) in an experimental orchard of NE Brazil.

Because the orchard was pin-monomorphic and selfcompatible, it did not fit the conditions necessary to be classified as typically distylous (i.e., two floral morphs and self-incompatibility; Hamilton 1990). Atypical distyly has been recorded in the same family for Oxalis species (Arroyo et al. 2012; Weller et al. 2016; Baena-Díaz et al. 2012; Costa et al. 2017). Although atypical distyly is related to the collapse of mating systems in natural populations (Weber et al.
2013), here it may reflect the selection of genotypes with commercially valuable features.

Table 2. Floral morphometrics of Averrhoa carambola in an experimental orchard of NE Brazil. SD: standard deviation. Different superscript letters indicate statistically different values (Wilcoxon rank sum test).

\begin{tabular}{|c|c|}
\hline Floral trait & Mean \pm SD $(\mathbf{m m})$ \\
\hline Corolla length & $4.4 \pm 1.05$ \\
\hline Corolla diameter & $9.85 \pm 1.61$ \\
\hline Corolla tube diameter & $2.42 \pm 0.50$ \\
\hline Stigma height & $4.67 \pm 0.58 \mathrm{a}$ \\
\hline Anther height & $3.16 \pm 0.58 \mathrm{~b}$ \\
\hline Stigma-anther separation & $1.51 \pm 0.59$ \\
\hline
\end{tabular}

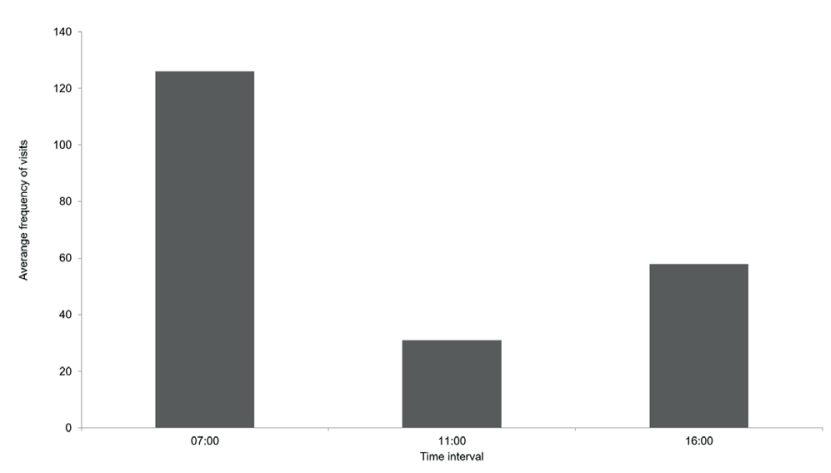

Figure 2. Frequency of floral visits observed in Averrhoa carambola in an experimental orchard of NE Brazil.

Self-compatibility is thought to contribute to reproductive assurance (Cruzan \& Barrett 2016), although the herkogamy observed here appears to drastically reduce selfing, as fruit set after SS was very low (4\%). In addition to reducing self-fertilization, herkogamy is also thought to reduce interference between male and female functions within the flower and maximize pollen receipt and dispatch - thus enhancing cross pollination rates (Lloyd \& Webb 1986; Chen 2012). That assumption was confirmed, as fruit set after NP was 10 times higher than after SS (DDP $=0.9$ ), reinforcing the presumed dependence of star fruit yields on pollinators (Giannini et al. 2015a). Therefore, despite being self-compatible, cross pollination has a great influence on fruit production, as fruit set after $\mathrm{CP}$ was 13fold higher than after SS. The PLI calculations revealed that the orchard experiences a low degree of pollen limitation, even though the plants could set more fruits if more pollen was deposited onto the stigmas.

The orchard was pollinated exclusively by A. mellifera, which is the most widely used pollinator of commercial crops (Garibaldi et al. 2013), and those bees have been recommended to improve star fruit production (Ray 2002). Other studies have recorded bees of the genera Trigona as efficient pollinators of star fruits (Phoon 1985; Cabreira et al. 2011; Silva-Junior 2016). Apis mellifera and Trigona are both well-adapted to small, actinomorphic flowers with 


\section{Crop yield mediated by honeybees in a star fruit orchard exhibiting atypical distyly}

short corolla tubes, such as those of $A$. carambola. Those same floral features are commonly observed in distylous species and appear to favor pollen transfer, as they allow easy access to both floral resources and sexual elements (Barrett \& Shore 2008). The pollination efficiency A. mellifera was high, as a single visit was enough to assure half of the fruit set observed in NP.

Although A. mellifera was an efficient pollinator, the PLI results suggest the necessity of pollinator management in order to improve crop yields. As such, we encourage the experimental introduction of native bee species in the place of A. mellifera, as the former have been recorded as efficient pollinators of star fruit flowers and play important roles in crop production worldwide (Garibaldi et al. 2013). Although Apis mellifera was an efficient pollinator of star fruit flowers, that species is known to have negative impacts on several plant-pollinator relationships (Valido et al. 2019). Native bee species would improve fruit production by performing cross pollinations, as the orchard is pin-monomorphic, and fruit set after cross-pollination was found to be much higher than by spontaneous self-pollination.

In face of the heterogeneous visitation distribution rate during the day, we recommend the use of pesticides (definitely an unfriendly pollinator practice, IPBES 2016) only when absolutely necessary, and spraying should not occur during periods of high visitation (near 07:00 and 16:00).

Additional studies will be needed to determine if the atypical condition encountered here (i.e., pinmonomorphism associated with self-compatibility) is only a local phenomenon or if it occurs in other orchards, as it is directly related to pollinator dependence. It would be informative to compare crop yields between monomorphic, dimorphic, and isoplethic (i.e., with similar proportion of pin and thrum individuals) orchards, as the latter condition is known to favor fruit set in distylous species (Barrett \& Shore 2008). The presence of thrum individuals in the orchard may enhance selfing, as their stamens are longer than their stigmas, and pollen can fall by gravity or easily deposited onto the stigmas by bees when foraging on the flower (Ree 1997). It would therefore also be interesting to determine to what extent the relative abundances of pin and thrum morphs affect crop yields, as, despite the fact that thrum individuals may enhance selfing, they are essential for the isoplethy condition that increases fruit set.

\section{Acknowledgements}

We thank the Coordenação de Aperfeiçoamento de Pessoal de Nível Superior for the scholarship granted to R.R.Novo, the Conselho Nacional de Desenvolvimento Científico e Tecnológico - CNPq for the research grant C.C. Castro (483348/2012-0) and E.L.A. (303504/2018-8), the Programa de Pós-Graduação em Botânica-Universidade
Federal Rural de Pernambuco for the logistical and financial support, the Instituto Agronômico de Pernambuco - IPA for the logistical support and the anonymous reviewers for their suggestions on the manuscript.

\section{References}

Arroyo MTK, Humana AM, Domínguez D, Jespersen G. 2012. Incomplete trimorphic incompatibility expression in Oxalis compacta Gill. ex Hook. et Arn. subsp. compacta in the central Chilean Andes. Gayana Botanica 69: 88-99.

Ayres M, Ayres Júnior M, Ayres DL, Santos ADA. 2007. Aplicações estatísticas nas áreas das ciências biomédicas. https://www.mamiraua. org.br. 2 Jan. 2018.

Baena-Díaz F, Fornoni J, Sosenski P, et al. 2012. Changes in reciprocal herkogamy during the tristyly-distyly transition in Oxalis alpina increase efficiency in pollen transfer. Journal of Evolutionary Biology 25: 574-583.

Barrett SCH, Shore JS. 2008. New insights on heterostyly: comparative biology, ecology and genetics. In: Franklin-Tong EV. (ed.) Selfincompatibility in flowering plants: evolution, diversity, and mechanisms. Berlim, Springer. p. 3-32.

Bastos DC. 2004. A cultura da carambola. Revista Brasileira de Fruticultura 26: 193-384.

Cabreira DMB, Biondo PLTA, Bezerra TM, Trindade TA, Ribeira JES, Kaminski AC. 2011. Visitantes florais de carambola, Averrhoa carambola L. (Oxalidaceae) na região do Médio Solimões, Amazonas, Brasil. Goiânia, Resumos da $63^{\text {a }}$ Reunião Annual da Sociedade Brasileira para o Progresso da Ciência, Brasil. http://www.sbpcnet.org.br/livro/63ra/ resumos/resumos/4837.htm. 01 Jan. 2020.

Castro CC, Oliveira PEAM, Alves MC. 2004. Breeding system and floral morphometry of distylous Psychotria L. species in the Atlantic rain forest, SE Brazil. Plant Biology 6: 755-760.

Chen ML. 2012. Floral morphology and breeding system in Polygonum hastato-sagittatum Mak. (Polygonaceae). Flora 207: 365-371.

Costa J, Ferrero V, Castro M, Loureiro J, Navarro L, Castro S. 2017. Variation in the incompatibility reactions in tristylous Oxalis pes-caprae: largescale screening in South African native and Mediterranean basin invasive populations. Perspectives in Plant Ecology, Evolution and Systematics 24: 25-36.

Crane JH. 1994. The carambola (star fruit). University of Florida. Florida Cooperative Extension Service. Fact Sheet HS-12, April 1994. https:// www.doc-developpement-durable.org/file/Culture/Arbres-Fruitiers/ FICHES_ARBRES/Carambolier/Carambola\%20Star\%20Fruit.pdf.

Cruzan MB, Barrett SC. 2016. Postpollination discrimination between self and outcross pollen covaries with the mating system of a selfcompatible flowering plant. American Journal of Botany 103: 568-576.

Dafni A, Kevan PG, Husband BC. 2005. Practical pollination biology. Ontario, Enviroquest Ltd.

Freitas L, Wolowski M, Sigiliano MI. 2010. Ocorrência de limitação polínica em plantas de Mata Atlântica. Oecologia Australis 14: 251-265.

Fushimi N. 1998. Studies on incompatibility pollination and floral morphological polymorphism of carambola (Averrhoa corambola L.). MSc. Thesis, University Putra Malaysia, Malasya.

Ganders FR. 1979. The biology of heterostyly. New Zealand Journal of Botany 17: 607-635.

Garibaldi LA, Aizen MA, Klein AM, Cunningham SA, Harder LD. 2011. Global growth and stability of agricultural yield decrease with pollinator dependence. Proceedings of the National Academy of Sciences 108: 5909-5914.

Garibaldi LA, Steffan-Dewenter I, Winfree R, et al. 2013. Wild pollinators enhance fruit set of crops regardless of honey bee abundance. Science 339: 1608-1611.

Giannini TC, Boff S, Cordeiro GD, Freitas BM, Saraiva AM, ImperatrizFonseca VL. 2015a. The dependence of crops for pollinators and the economic value of pollination in Brazil. Journal of Economic Entomology 108: 849-857. 


\section{Reinaldo Rodrigo Novo, Natan Messias de Almeida, Tulio Freitas Filgueira de Sá, Luiz Gonzaga Biones Ferraz, Elcida de Lima Araujo and Cibele Cardoso Castro}

Giannini TC, Boff S, Cordeiro GD, et al. 2015b. Crop pollinators in Brazil: a review of reported interactions. Apidologie 46: 209- 223

Goodwin RM, Cox HG, Taylor MA, Evans LJ, McBrydie HM. 2011. Number of honey bee visits required to fully pollinate white clover (Trifolium repens) seed crops in Canterbury, New Zealand. New Zealand Journal of Crop Horticultural Science 39: 7-19.

Hamilton CW. 1990. Variations on a distylous theme in Mesoamerican Psychotria subgenus Psychotria (Rubiaceae). Memoirs of the New York Botanical Garden 55: 65-75.

IPBES. 2016. The assessment report of the Intergovernmental SciencePolicy Platform on Biodiversity and Ecosystem Services on pollinators, pollination and food production. In: Potts SG, Imperatriz- Fonseca VL, Ngo HT, et al. (eds.) Secretariat of the Intergovernmental SciencePolicy Platform on Biodiversity and Ecosystem Services, Bonn. http:// nora.nerc.ac.uk/id/eprint/519227/. 20 Jan. 2020.

Jacquemyn H, Gielen M, Brys R. 2018. Is sexual organ reciprocity related to legitimate pollen deposition in distylous Pulmonaria (Boraginaceae)? Oikos 127: 1216-1224.

Klein AM, Steffan-Dewenter I, Tscharntke T. 2003. Fruit set of highland coffee increases with the diversity of pollinating bees. Proceedings of the Royal Society B 270: 955-961.

Klein AM, Vaissiere BE, Cane JH, et al. 2007. Importance of pollinators in changing landscapes for world crops. Proceedings of the Royal Society B 274: 303-313.

Knight Jr RJ. 1965. Heterostyly and pollination in carambola. Proceedings of the Florida State Horticultural Society 78: 375-78.

Lautenbach S, Seppelt R, Liebscher J, Dormann CF. 2012. Spatial and temporal trends of global pollination benefit. PLOS ONE 7: e35954. doi: 10.1371/journal.pone.0035954

Lázaro A, Lundgren R, Toland Ø. 2014. Pollen limitation, species' floral traits and pollinator visitation: different relationships in contrasting communities. Oikos 124: 174-186.

Lloyd DG, Webb CJ. 1986. The avoidance of interference between the presentation of pollen and stigmas in angiosperms II. Herkogamy. New Zealand Journal of Botany 24: 163-178.

Núñez-Elisea R, Crane JH. 2000. Selective pruning and crop removal increase early-season fruit production of carambola (Averrhoa carambola L.). Scientia Horticulturae 86: 115-126.

Phoon ACG. 1985. Insect pollination of some Malaysian fruit trees with special reference to the honey bee, Apis cerana. MSc. Thesis, Universiti Pertanian, Malaysia.
Potts SG, Biesmeijer JC, Kremen C, Neumann P, Schweiger O, Kunin WE. 2010. Global pollinator declines: trends, impacts and drivers. Trends in Ecology \& Evolution 25: 345-353.

Potts SG, Imperatriz-Fonseca V, Ngo HT, et al. 2016. Safeguarding pollinators and their values to human well-being. Nature 540: 220-229.

R Development Core Team. 2015. R: a language and environment for statistical. R Foundation for Statistical Computing, Vienna. https:// www.R-project.org/. 15 Feb. 2020.

Ray PK. 2002. Breeding tropical and subtropical fruits. Berlin, SpringerVerlag.

Ree RH. 1997. Pollen flow, fecundity, and adaptive significance of heterostyly in Palicourea padifolia (Rubiaceae). Biotropica 29: 298-308.

Rollin O, Garibaldi LA. 2019. Impacts of honeybee density on crop yield: A meta-analysis. Journal of Applied Ecology 56: 1152-1163.

Sakai S, Wright SJ. 2007. Reproductive ecology of 21 coexisting Psychotria species (Rubiaceae): when is heterostyly lost? Biological Journal of the Linnean Society 93: 125-134.

Saúco VG, Menini UG, Tindall HG. 1993. Carambola cultivation. Rome, Food \& Agriculture Organization of the United Nations-FAO.

Silva-Junior CG. 2016. Polinização na caramboleira (Averrhoa carambola L.) por Apis mellifera L: requerimentos da cultura e eficiência do polinizador. MSc Thesis, Universidade Federal Rural de Pernambuco, Garanhuns.

Smith MR, Singh GM, Mozaffarian D, Myers SS. 2015. Effects of decreases of animal pollinators on human nutrition and global health: a modelling analysis. The Lancet 386: 1964-1972.

Valido A, Rodríguez-Rodríguez MC, Jordano P. 2019. Honeybees disrupt the structure and functionality of plant-pollinator networks. Scientific Reports 9: 1-11.

Weber JJ, Weller SG, Sakai AK, et al. 2013. The role of inbreeding depression.n and mating system in the evolution of heterostyly. Evolution 67: 2309-2322.

Weller SG, Sakai AK, Gray T, et al. 2016. Variation in heterostylous breeding systems in neighbouring populations of Oxalis alpina (Oxalidaceae). Plant Biology 18: 104-110.

Wolowski M, Agostini K, Rech RR, et al. 2019 Relatório temático sobre polinização, polinizadores e produção de alimentos no Brasil. São Carlos, Editora Cubo.

Wong KC, Watanabe M, Hinata K. 1994. Fluorescence and scanning electron microscopic study on self-incompatibility in distylous Averrhoa carambola L. Sexual Plant Reproduction 7: 116-121. 